\title{
Management Dysfunction in Optimizing the General Education System
}

\author{
Volodymyr V. Hoblyk ${ }^{*}$, Vladimir I. Savinkov², Boris Z. Doktorov ${ }^{3}$, and Frants E. Sheregi ${ }^{4}$ \\ ${ }^{1}$ Ds of Economics, Professor, Vice-rector, Mukachevo State University, Mukachevo, Ukraine \\ ${ }^{2}$ Doctor of Sociology, Professor, Russian State University for the Humanities, Moscow, Russia \\ ${ }^{3}$ Doctor of Philosophy, University of Nevada, Las Vegas, USA \\ ${ }^{4}$ Candidate of Philosophy, Center of Social Forecasting and Marketing, Moscow, Russia
}

\begin{abstract}
The optimization of Russian secondary education carried out in 2010-2014 intending to strengthen the role of municipal authorities had some negative consequences. For instance, territorial educational authorities started receiving complaints about the violation of labor standards, and teachers began to quit their jobs. The purpose of this paper is to study the dependence of the dysfunctions manifested in the general education system on the management methods used by municipal authorities. The research method involves an all-Russian representative expert survey (2018) of specialists employed at territorial and municipal education authorities. The results of the study showed that the cause of destructive phenomena that had occurred in the field of work regulation of the general education system and made teachers quit their jobs was the domination of the administrative principle in the selection of personnel at the municipal level. The prescriptive management methods began to prevail at schools because the optimization of schools and changes in teacher standards in connection with higher teachers' salaries were supervised by federal educational authorities, which stimulated municipal authorities to strengthen directorial management methods in the interests of the successful implementation of the optimization program. For this reason, municipal authorities began to select specialists with good managerial abilities, paying less attention to their creative side. The study showed that the priority of directive character in the work of municipal education administration bodies was generated by the excessive role of federal bodies in coordinating the territorial education system in labor-regulating and financial aspects. Conclusion: the federal system of general education management needs to be decentralized and creativity should be prioritized in the selection of specialists for municipal education authorities.
\end{abstract}

\section{Introduction}

The Russian Federation (RF) is characterized by a pyramidal structure for managing the education system in terms of standardizing the work of teachers and financial subsidies for educational organizations: the first level is occupied by the Ministry of education of the RF,

* Corresponding author: hoblik v@ukr.net 
which implements the functions of the overall coordination of the education system; the second level — by the territorial bodies of education management (of the constituent entities of the RF), carrying out the management of the corporate and supervisory type; the third level - by municipal education authorities with directory and supervisory functions; the fourth level — by educational organizations with the administrative and technological type of management. The preservation of multilayer hierarchical education management is caused by the need for a prompt response by federal government bodies to the mass migration of youth from villages to cities (more than 20 million people over the past 30 years), the restructuring of many rural schools, and the expansion of the potential of urban schools that accept children from families of former rural residents. Besides, $60 \%$ of the constituent entities of the RF have a budget deficit and need federal subsidizing of municipal educational organizations, which requires maintaining federal control over the implementation of subsidies [1]. The optimization of the territorial structure of general education has not been completed: the share of students in rural schools is $21.5 \%$ of the total number of students in Russian schools, while the number of rural schools amounts to $57 \%$ of the total number of schools in Russia [2].

The optimization of the general education system in 2010-2014 carried out to expand the functions of the municipal educational authorities gave the opposite result from what had been intended: the educational authorities at various levels began to receive complaints from teachers about the violation of labor standards, and teachers began to quit their jobs [3]. The workload of teachers in the framework of their main activities in many schools exceeds the norm: more than $45 \%$ of teachers in schools work 2 hours more than normal; the maximum teaching workload per week reaches 30 hours for many teachers. According to the data of the study conducted by us, up to $40 \%$ of teachers feel constant physical fatigue, and up to $30 \%$ complain of psychological fatigue [4].

It was necessary to study the causes of these negative phenomena, for which an allRussian representative study (a survey of experts) was conducted in 2018. The empirical data discussed below are the result of this study.

\section{Methods}

A nationwide representative expert survey was conducted in 2018 by the Center for social forecasting and marketing with our participation. The method of collecting primary information is a formalized personal interview with a quota selection of experts. The Ministry of education and science of the RF provided statistical information on the territorial structure of the general population of experts - employees of territorial and municipal education management bodies to form the parameters of quotas for selection of experts by interviewers. The survey was conducted among 1,745 municipal employees (in 349 municipalities) and 255 employees of territorial education authorities (in 85 subjects of the RF).

\section{Discussion}

Previous studies conducted by specialists showed that the personnel of the territorial and municipal education administration bodies comprised a highly professional team, they took their professional responsibilities creatively, performing their functions in combination with a sense of civic duty $[5,6]$. However, the territorial optimization of schools and the change in the labor standards of teachers, which was required in connection with the increase in their salaries, were supervised by the federal educational authorities, which, as shown by the results of a study conducted by the Center for social forecasting and marketing with our participation, led to several serious problems, such as violation of normative indicators for 
teachers' work, the excessive workload of teachers in the framework of their main activities, and unreasonable extracurricular workload [4]. The results of the study allowed us to formulate a hypothesis that the cause of negative phenomena in schools lied in the destructive logistics of management at the municipal level. This hypothesis had also been formulated by the experience of foreign researchers [7,8]. To test this hypothesis, a separate study was conducted with our participation and further presentation of the material is based solely on the empirical indicators of this study.

According to the research, for most specialists, joining the education management system is the result of career growth or moving from a provincial city. The average age of specialists of municipal education authorities optimal for this work equals 43 years. At least $90 \%$ of employees of municipal education authorities have a specialized higher education. The style of their work is characterized by scientifically based logistics of decision-making: preliminary analysis of the problem to improve the level of competence of decisions.

One of the major problems that characterize the work of municipal education authorities is that most specialists do not understand the trajectory of their career $[9,10]$. According to the interviewed experts employed at territorial education authorities, this is because only $40 \%$ of municipal education authorities have long-term plans for professional and age-based rotation of personnel. However, the existing staff rotation plans have not been fully developed: on a five-point scale, specialists of territorial education authorities rated the effectiveness of the staff rotation plan of municipal education authorities by 3.2 points. Such dysfunction in the municipal education management bodies is fraught with an increase in the share of older personnel, the need for their accelerated mass rotation, and the loss of professional and industrial continuity in the team of specialists [11].

Despite the high educational level and long teaching experience of the specialists employed at municipal education authorities, the experts of territorial education authorities assess their level of qualification by only 3.5 points on a five-point scale. This is the result of the fact that, as the study showed, when selecting personnel for work in the municipal education administration, two characteristics are mainly taken into account: the presence of pedagogical education and the years of teaching experience. In $40 \%$ of municipal education authorities, the staff is selected on the recommendation of representatives of the local executive authority, and these recommendations are often subjective. Due to the complexity of recruitment, $40 \%$ of municipal education authorities search for staff through advertising, recruitment agencies, the Internet, and employment services. When selecting personnel for a municipal education management body, the applicant's ability to perform managerial work, the ability to anticipate the consequences of decisions made, and the willingness to take responsibility for possible risks are often ignored. In the absence of such qualities, the pace of work of a specialist becomes slow, their initiative is hindered by doubts and indecision, as evidenced by the foreign experience of such research [12, 13, 14].

Specialists of municipal education authorities themselves most often use traditional forms of communication with the object of management in their work: mobile phone communication (17\%), computer technology (28\%), landline telephone communication $(15 \%)$, trips to contact school headmasters and teachers $(11 \%)$, inviting school headmasters to the municipal education authority for a meeting $(11 \%)$, informing school management through printed documents (13\%), sending employees to monitor the work of schools $(6 \%)$.

An analysis of the research data showed that the listed problems in the work of municipal education authorities did not have a decisive impact on the destructive phenomena in the work of schools and did not hinder the work of teachers. The main reason for the problems that arose in the work of teachers is that the territorial optimization of schools and changes in the labor standards of teachers, in connection with the increase in their salaries, were under the supervision of federal education authorities, which stimulated municipal authorities to strengthen policy methods in their work. This, in turn, led to the fact that the municipal 
education authorities began to select personnel mainly for directive management, ignoring their creative qualities.

The analysis of the results of the expert survey suggests that under conditions of excessive dynamism of the Russian general education system due to its structural and territorial optimization, the municipal education authorities find it difficult to form a unified approach to recruitment, the legislative component of management functions becomes more important, and the requirement for the principles of education management staff to be democratic loses its importance. This is also confirmed by the results of foreign studies of the practice of education management at the municipal level $[15,16]$.

\section{Conclusion}

Based on the analysis of empirical data from an expert survey, we have concluded that the priority of directives in the work of municipal education authorities is generated by the multilayered hierarchical structure of education system management that exists in Russia on a federal scale, and by the dominating role of federal authorities in coordinating the territorial education system in the regulatory and financial aspects.

Therefore, a deeper restructuring of the federal system of general education management is required, as well as a change in the criteria for recruitment of personnel for municipal education authorities, taking into account the priority of creativity over administrative qualities. It is also advisable to involve a wide range of researchers in the field of education management to develop principles for decentralizing the management process in the general education system of the RF, taking into account the upcoming expansion of elements of distance education, the introduction of which is inevitable in connection with the adoption of the state digitalization program.

\section{References}

1. F.E. Sheregi, A.L. Arefev, Education Management Personnel. Sociological analysis (Yurait, Moscow, 2018)

2. Education in numbers. Ministry of Science and Higher Education, Ministry of Education, Rosstat, HSE (Rosstat, Moscow, 2019)

3. G.A. Klyucharyov, A.I. Savenkov, P.A. Baklanov, Sociological Studies 9(389), 117-125 (2016)

4. F.E. Sheregi, A.L. Arefev, P.E. Tsarkov, Working conditions for teachers: chronometric and sociological analysis (Center for Sociological Research, Moscow, 2016)

5. M.M. Potashnik, A.V. Solozhnin, Education management at the municipal level (Pedagogical Society of Russia, Moscow, 2012)

6. A.A. Shabunova, G.V. Leonidova, M.A. Golovchin, Education: regional problems of quality management (ISEDT RAS, Moscow, 2012)

7. I. K. Ronen, Studies in Educational Evaluation 64, 1-9 (2020)

8. A. K. Lund, Scandinavian Journal of Management 35, 1-10 (2019)

9. Yu. F. Zakariyaa, K. Bjorkestola, H.K. Nilsena, S. Goodchilda, M. Lorasb, Studies in Educational Evaluation 64, 1-10 (2020)

10. N. A. Pauflera, E.F. Sloatb, Studies in Educational Evaluation 64, 1-15 (2020)

11. P. Garaudel, Scandinavian Journal of Management 36, 1-16 (2020)

12. L. Kyriakides, M. Anthimou, Studies in Educational Evaluation 64, 1-14 (2020) 
13. B. Shena, B. Baib, W. Xuec, Studies in Educational Evaluation 64, 1-10 (2020)

14. S. Sirris, Scandinavian Journal of Management 35, 1-12 (2019)

15. A. McFaddena, K. E. Williamsb,Studies in Educational Evaluation 64, 1-17 (2020)

16. E. S. Johnsona, Yu. Zhengb, A. R. Crawfordb, L. A. Moylanb, Studies in Educational Evaluation 64, 1-9 (2020) 